\title{
New data about atrial fibrillation, comment to the OFRECE study: response
}

\author{
Juan José Gómez-Doblas, Javier Muñiz, Joaquín J. Alonso Martín, Eulalia Roig
}

\section{To the Editor,}

We appreciate the interest shown by Vidal-Pérez et al. in our article published recently in Revista Española de Cardiología, ${ }^{1}$ which provides us with an opportunity to present some interesting additional information not included in the article itself. We agree on the importance of knowing the thromboembolic risk of the population included in the OFRECE study, both for patients with a diagnosis of atrial fibrillation and for the general population. In our study, the mean (standard deviation) $\mathrm{CHADS}_{2}$ and $\mathrm{CHAD}_{2} \mathrm{DS}_{2}$-VASc of patients with atrial fibrillation was 2.3 (1.3) and 3.8 (1.6), respectively. In the general population, the mean (standard deviation) $\mathrm{CHADS}_{2}$ and $\mathrm{CHAD}_{2} \mathrm{DS}_{2}-\mathrm{VASc}$ of patients with atrial fibrillation was 0.8 (1) and $1.8(1.5)$, respectively. The distribution of both scales is in agreement with that of the Val-FAAP and AFABE studies, ${ }^{2,3}$ although the similarity is greater in the 2 population-based studies (Figure). These data are, we believe, relevant because they show that the level of risk in the population with atrial fibrillation is very similar to that of the populations included in clinical trials with new oral anticoagulants. In addition, an increasing body of evidence suggests that thromboembolic risk, as measured with these scales in the population without a diagnosis of atrial fibrillation, is associated with the onset of events. ${ }^{4}$

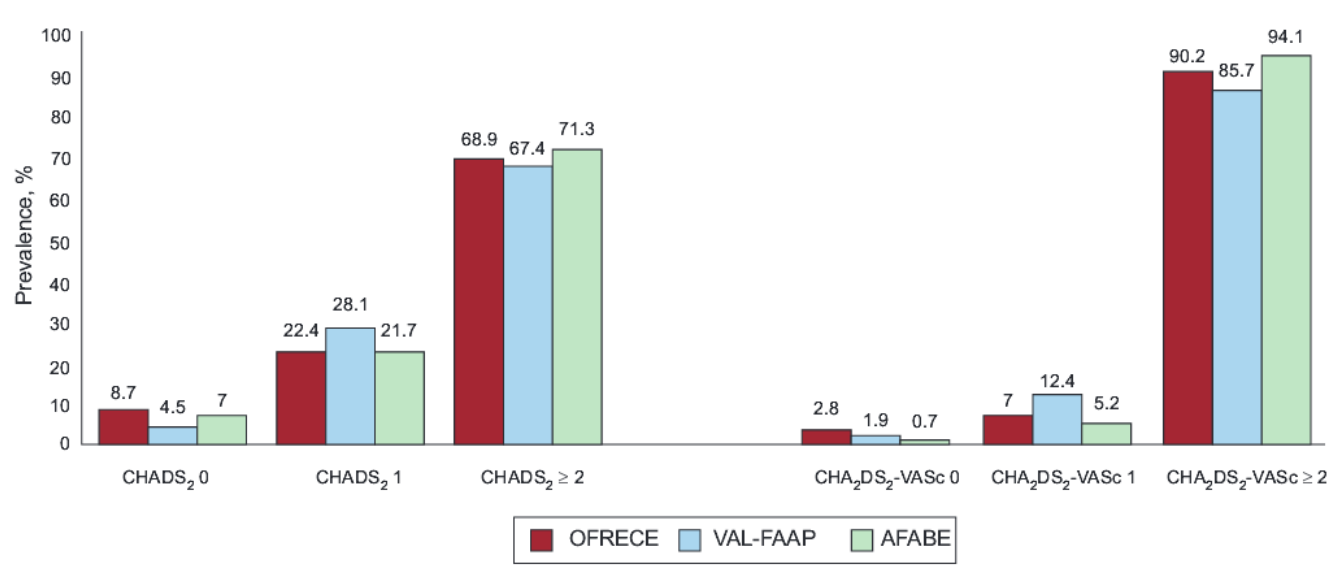

Figure. Prevalences by thromboembolic risk scales in the OFRECE, AFABE, and Val-FAAP studies.

\section{Bibliography}

1.Gómez-Doblas JJ, Muñiz J, Alonso Martin JJ, Rodríguez-Roca G, Lobos JM, Awamleh P, et al. Prevalencia de fibrilación auricular en España Resultados del estudio OFRECE. Rev Esp Cardiol. 2014; 67:259-69.

2.Barrios V, Calderón A, Escobar C, de la Figuera M. Pacientes con fibrilación auricular asistidos en consultas de atención primaria Estudio Val-FAAP. Rev Esp Cardiol. 2012; 65:47-53.

3.Clua-Espuny JL, Lechuga-Duran I, Bosch-Princep R, Roso-Llorach A, Panisello-Tafalla A, Lucas-Noll J, et al. Prevalencia de la fibrilación auricular desconocida y la no tratada con anticoagulantes. Estudio AFABE. Rev Esp Cardiol. 2013; 66:545-55.

4.Ntaios G, Lip GY, Makaritsis K, Papavasileiou V, Vemmou A, Koroboki E, et al. CHADS $2 . \mathrm{CHA}_{2} \mathrm{~S}_{2} \mathrm{DS}_{2}-\mathrm{VASc}$, and long-term stroke outcome in patients without atrial fibrillation. Neurology. 2013; 80:1009-17. 